\title{
"Digital business research for small and medium-sized enterprises: The case of Ukraine"
}

\begin{tabular}{|c|c|}
\hline \multirow{5}{*}{ AUTHORS } & Anton Kvitka (D http://orcid.org/0000-0002-5730-1352 \\
\hline & Anna Kramarenko (D http://orcid.org/0000-0001-5987-1247 \\
\hline & Denys Davydov (D http://orcid.org/0000-0002-8323-1597 \\
\hline & Maryna Pasmor (D http://orcid.org/0000-0002-3788-5688 \\
\hline & Olga Diachek (D http://orcid.org/0000-0002-7285-6401 \\
\hline ARTICLE INFO & $\begin{array}{l}\text { Anton Kvitka, Anna Kramarenko, Denys Davydov, Maryna Pasmor and Olga } \\
\text { Diachek (2021). Digital business research for small and medium-sized } \\
\text { enterprises: The case of Ukraine. Problems and Perspectives in Management, } \\
\text { 19(1),177-184. doi:10.21511/ppm.19(1).2021.15 }\end{array}$ \\
\hline DOI & http://dx.doi.org/10.21511/ppm.19(1).2021.15 \\
\hline RELEASED ON & Friday, 26 February 2021 \\
\hline RECEIVED ON & Wednesday, 07 October 2020 \\
\hline \multirow[t]{2}{*}{ ACCEPTED ON } & Wednesday, 17 February 2021 \\
\hline & $(\mathrm{coc})$ EY \\
\hline LICENSE & $\begin{array}{l}\text { This work is licensed under a Creative Commons Attribution } 4.0 \text { International } \\
\text { License }\end{array}$ \\
\hline JOURNAL & "Problems and Perspectives in Management" \\
\hline ISSN PRINT & $1727-7051$ \\
\hline ISSN ONLINE & $1810-5467$ \\
\hline PUBLISHER & LLC "Consulting Publishing Company "Business Perspectives" \\
\hline FOUNDER & LLC "Consulting Publishing Company "Business Perspectives" \\
\hline
\end{tabular}

NUMBER OF REFERENCES

30

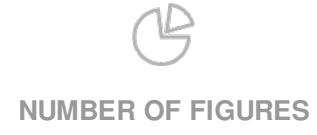

0

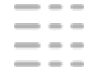

NUMBER OF TABLES

7

C The author(s) 2021. This publication is an open access article. 


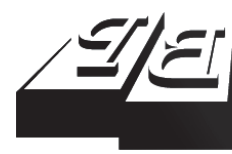

\section{BUSINESS PERSPECTIVES}

()

LLC "CPC "Business Perspectives" Hryhorii Skovoroda lane, 10, Sumy, 40022, Ukraine www.businessperspectives.org

Received on: $7^{\text {th }}$ of October, 2020 Accepted on: $17^{\text {th }}$ of February, 2021 Published on: $26^{\text {th }}$ of February, 2021

(C) Anton Kvitka, Anna Kramarenko, Denys Davydov, Maryna Pasmor, Olga Diachek, 2021

Anton Kvitka, Ph.D. (Economics), Associate Professor, Deputy Director of the Educational and Scientific Institute "Karazin Business School", V. N. Karazin Kharkiv National University, Kharkiv, Ukraine.

Anna Kramarenko, Ph.D. (Economics) Senior Lecturer at the Department of Management and Administration, Educational and Scientific Institute

"Karazin Business School", V. N. Karazin Kharkiv National University, Kharkiv, Ukraine. (Corresponding author)

Denys Davydov, Ph.D. (Economics), Associate Professor, Associate Professor of the Department of Management and Administration, Educational and Scientific Institute "Karazin Business School”, V.N. Karazin Kharkiv National University, Kharkiv, Ukraine.

Maryna Pasmor, Ph.D. (Economics), Associate Professor of the Department of Management and Administration, Educational and Scientific Institute "Karazin Business School," V. N. Karazin Kharkiv National University, Kharkiv, Ukraine.

Olga Diachek, Ph.D. (Economics), Associate Professor of the Department of Mathematical Methods in Economics, School of Economics, V. N. Karazin Kharkiv National University, Kharkiv, Ukraine.

This is an Open Access article, distributed under the terms of the Creative Commons Attribution 4.0 International license, which permits unrestricted re-use, distribution, and reproduction in any medium, provided the original work is properly cited.

Conflict of interest statement: Author(s) reported no conflict of interest
Anton Kvitka (Ukraine), Anna Kramarenko (Ukraine), Denys Davydov (Ukraine), Maryna Pasmor (Ukraine), Olga Diachek (Ukraine)

\section{DIGITAL BUSINESS RESEARCH FOR SMALL AND MEDIUM-SIZED ENTERPRISES: THE CASE OF UKRAINE}

\begin{abstract}
The use of available digital tools, the entrepreneur's personal human capital, and the formation and filling of niche markets are seen as the main factors of enterprises' prosperity. Thus, the study aims to identify the impact of business research on the dynamics of operational and commercial efficiency of small and medium-sized enterprises (SME). The online survey and regression analysis methods based on the data obtained were used. The study revealed that SMEs constantly need to perform data analysis, but despite the need for business intelligence, enterprises rarely use Big Data (cloud technologies). Most small businesses that conduct business research use digital tools, which poses acute problems of staff development and building an effective model for outsourcing research agents. Currently, the economic efficiency of business research is not clearly visible, which is due to the influence of strong external factors, as well as a low level of innovation and research activity of economic agents.
\end{abstract}

Keywords

research agents, organizational innovations, business analytics, Big Data, cloud technologies

JEL Classification M10, M21

\section{INTRODUCTION}

Recent research shows that small and medium-sized enterprises (SMEs) provide the basis for economic growth both in Europe and around the world (Răzvan, 2019). In particular, 99\% of European Union (EU) companies are small and medium-sized enterprises (Fazal et al., 2020); small and medium-sized enterprises employ two-thirds of the EU workforce (Al-Tal \& Emeagwali, 2019); SMEs generate about $60 \%$ of the EU GDP (Hamburg et al., 2017). Nevertheless, in a highly competitive environment, the problem of survival and scaling is particularly acute for small and medium-sized businesses (Anderson et al., 2014; Chen \& Fan, 2013). The main factors for the prosperity of modern enterprises are the use of available digital tools (Buntak et al., 2020), the entrepreneur's personal human capital (intellectual and emotional capital, skills, abilities) (Peček \& Ovsenik, 2018), and the formation and filling of niche markets (Kvitka \& Kramarenko, 2018).

According to empirical research, the transition to the digital economy and the increasing role of business platforms are driving innovation for small and medium-sized businesses, primarily within the value proposition of the business model (Alpeza et al., 2018). Analytical findings from a sample of small businesses show that connecting to business platforms creates advantages for small businesses such as promotion through network effects and communities of users/service providers, global business scaling, and opening up new sources of value creation (Ruggieri et al., 2018). The main issue is how to use digital 
tools to scale SMEs and maintain their competitive position. In the Ukrainian economy, digital opportunities for small businesses are more limited compared to European enterprises. Thus, the search for effective strategies for implementing digital technologies in business practice is very relevant.

\section{LITERATURE REVIEW}

One of the reasons why small and medium-sized enterprises have increased their influence on the market environment is that they are ideal incubators for various types of innovation (Al-Tal \& Emeagwali, 2019; Nemoto \& Koreen, 2019). In modern conditions, there are two main advantages for small and medium-sized businesses:

- market demand and its specific parameters are determined at the micro level (Kostrzewska \& Wrukowska, 2019);

- SMEs do not need to defend their market positions, as in many cases they are new to the market or are creating it (Wynarczyk, 2013).

Many researchers believe that a high level of innovation (technological creativity, the emergence of commercial ideas and projects) is associated with the spread of digital technologies (Alpeza et al., 2018; Ruggieri et al., 2018), such as cloud computing, data analysis, and enterprise resource planning software (Ogrean, 2018). Companies that use Big Data are more likely to innovate and increase productivity by $5-10 \%$ (Perko \& Ototsky, 2016). However, the spread of advanced ICTs remains insufficient to realize the economic potential of both individual enterprises and national economies (Kvitka \& Kramarenko, 2020). According to European practice, the public sector and SMEs lag behind the most. In particular, less than 25\% of small businesses use cloud computing (Rooney, 2017). With the declining role of large corporations in the global economic arena, digital technologies offer SMEs a unique opportunity to increase their influence (Davydov et al., 2020).

Digital tools include cloud technologies, multifunctional platforms, Big Data, the Internet of Things, 3D printing, and artificial intelligence (Rissola \& Sorvik, 2018). The widespread adoption of these technologies in the third wave of digitalization has increased their availability (Saunila, 2016). Through a worldwide network based on the postulates of openness, SMEs can access and exchange data, knowledge and technologies, conduct joint research, and use specialized consulting services (Rooney, 2017). Since digital technologies enable the creation of a personalized new product (Spithoven et al., 2013), as well as reduce the time and improve the quality of decision-making (Todericiu \& Boanta, 2019), the reduction in their cost has increased the interest of entrepreneurs.

Current research provides insight into the degree of digitalization's impact on business in general (El-Haddadeh, 2019), as well as on social interaction processes (Kvitka \& Kramarenko, 2020). The special attention was paid to the study of the role played by digital tools in increasing the competitive advantages of small and medium-sized companies.

The factor of personal human capital has a significant impact on the ability to scale research projects. Personal human capital is considered by the authors as a combination of creativity, soft skills, technological literacy, leadership qualities, and professional baggage (skills obtained as a result of education and experience). In modern scientific publications, the concepts of personal, intellectual, and emotional capital are given considerable attention (Buntak et al., 2020; Peček \& Ovsenik, 2018). However, personal qualities that form the basis of human capital are considered as factors that determine the effectiveness of management, as well as the motivation and development of personnel. Thus, personal human capital forms the basis for improving the operational and commercial efficiency of companies. Considering the issue from this perspective allows identifying important patterns that are of practical importance for business.

Previous studies (Kvitka \& Kramarenko, 2018) have found that SMEs increase their influence on the economic development of EU countries, as well as on the dynamics of the Ukrainian economy. This raises the question of how to improve the efficiency of small businesses. Thus, this paper is a 
continuation of the study of problems and opportunities for the development of SMEs in the national economy of Ukraine.

In this study, the need, opportunities and prospects for the implementation of business research by small businesses are in the sphere of scientific interest. The business research was defined as a study of market conditions and consumer sentiment in order to identify new niches, areas of innovation, and improve the effectiveness of product promotion. Due to trends in consumer personalization and the development of niche markets, business research can create relevant scaling opportunities for SMEs. Since small companies have very limited financial resources to conduct business research, digital technologies are becoming the most accessible tool. The use of social media for market research (Andreva \& Kianto, 2011; Černe et al., 2016), cloud technologies for data storage and analysis (El-Haddadeh, 2019), cryptocurrencies for financial issues (Kramarenko et al., 2019) - all this is not a complete list of cheap and sometimes free ways to improve the efficiency of commercial and operational activities of SMEs.

\section{AIMS}

The paper aims to determine how much small businesses (using Ukrainian companies as an example) conduct business studies using this digital technology (cloud technology, social networking, Big Data) and the potential to create business research using digital tools to improve the efficiency of SMEs. To achieve the research goal, the areas where SMEs use digital tools need to be studied. Research questions are the determination of the need for business research for SMEs, as well as the purpose of conducting business research; the role of digital technologies in business research; the impact of business research on the dynamics of operational and commercial performance of small and medium-sized businesses.

\section{METHOD}

To implement the research goal, an online survey of small and medium-sized businesses was conducted. Based on official statistics available on the official website of the State Statistics Service of Ukraine, the data obtained were sorted out. To find out in which areas SMEs use digital tools, and to determine the purpose of conducting business research, survey results were subjected to a structural analysis. The structured data set was ranked to identify the role of digital technologies in business research and the impact of business research on the performance of small and medium-sized businesses through the use of regression analysis methods.

\section{RESULTS}

The study, based on statistical analysis of data obtained from a survey of representatives of Ukrainian small and medium-sized businesses, allowed assessing the degree of use of cloud computing, the intensity of business research. Many relationships were also identified between the dynamics of innovation, the performance of small businesses, and the intensity of the use of digital tools for business research.

According to the results of the analysis, most of small companies are constantly faced with the need to analyze data in their activities (Table 1).

Table 1. The results of the survey "Does your business require data analysis?"

Source: Calculated by the authors

\begin{tabular}{l|c|c|c}
\hline $\begin{array}{c}\text { Response } \\
\text { options }\end{array}$ & $\begin{array}{c}\text { Ranking of } \\
\text { response } \\
\text { options }\end{array}$ & $\begin{array}{c}\text { Number of } \\
\text { respondents } \\
\text { answers }\end{array}$ & $\begin{array}{c}\text { Share of the } \\
\text { total number } \\
\text { of responses, } \\
\%\end{array}$ \\
\hline Never & 1 & - & - \\
\hline Rarely & 2 & 8 & 6,11 \\
\hline Sometimes & 3 & 21 & 16,03 \\
\hline Often & 4 & 30 & 22,90 \\
\hline Constantly & 5 & 72 & 54,96 \\
\hline Total & - & 131 & 100 \\
\hline
\end{tabular}

More than half of the respondents (almost 55\%) say they constantly need to perform data analysis. According to the survey results, the main goals of business analytics are:

- $\quad$ planning ( $45 \%$ of respondents' answers);

- market research $(23 \%$ of respondents' answers);

- forecasting ( $13 \%$ of respondents' answers); 
- attracting resources (recruiting, fundraising) (3\% of respondents' answers);

- analysis of own activities (2\% of respondents' answers);

- professional development (1\% of respondents' answers);

- other (13\% of respondents' answers).

Many business opportunities for SMEs in the global market are created by Big Data. These opportunities are:

- $\quad$ search for and attract buyers with significant purchasing power;

- effective recruitment of new employees;

- fundraising and other types of outsourcing.

Despite this, only $11 \%$ of small businesses in the European community analyze Big Data. The study of small business in Ukraine showed that despite the need for business analytics, the studied enterprises also rarely use Big Data (about $17 \%$ of respondents use big data often or constantly) (Table 2).

Table 2. The results of the survey "How often do you use Big Data (cloud computing) in your business?"

\begin{tabular}{l|c|c|c} 
& \multicolumn{2}{c}{ Source: Calculated by the authors. } \\
\hline $\begin{array}{c}\text { Response } \\
\text { options }\end{array}$ & $\begin{array}{c}\text { Ranking of } \\
\text { response } \\
\text { options }\end{array}$ & $\begin{array}{c}\text { Number of } \\
\text { respondents' } \\
\text { answers }\end{array}$ & $\begin{array}{c}\text { Share of } \\
\text { the total } \\
\text { number of } \\
\text { responses, } \\
\%\end{array}$ \\
\hline Never & 1 & 71 & 54.19 \\
\hline Rarely & 2 & 33 & 25.19 \\
\hline Sometimes & 3 & 5 & 3.82 \\
\hline Often & 4 & 9 & 6.88 \\
\hline Constantly & 5 & 13 & 9.92 \\
\hline Total & - & 131 & 100 \\
\hline
\end{tabular}

The main goals of using Big Data are:

- customer search (29\% of respondents' answers);

- $\quad$ search for suppliers (7\% of respondents' answers);

- recruitment of employees (13\% of respondents' answers);

- internal and external analysis (5\% of respondents' answers).
The rare independent use of Big Data is partly due to the problems faced by consumers, namely small businesses. The most common ones are:

- $\quad$ system failure ( $12 \%$ of respondents' answers);

- false information $(10 \%$ of respondents' answers).

Along with this, European representatives of small and medium-sized businesses also state other risks associated with big data, in particular:

- loss of customer trust;

- fraud.

In most cases, users of cloud computing and specialized software components claim that there were no problems ( $48 \%$ of respondents' answers).

However, representatives of Ukrainian small businesses often face the need for business research (Table 3), but they rarely use digital tools (Table 4).

Table 3. The results of the survey "Do you need business research in your business?"

\begin{tabular}{l|c|c|c} 
& \multicolumn{2}{c}{ Source: Calculated by the authors. } \\
\hline $\begin{array}{c}\text { Response } \\
\text { options }\end{array}$ & $\begin{array}{c}\text { Ranking of } \\
\text { response } \\
\text { options }\end{array}$ & $\begin{array}{c}\text { Number of } \\
\text { respondents' } \\
\text { answers }\end{array}$ & $\begin{array}{c}\text { Share of } \\
\text { the total } \\
\text { number of } \\
\text { responses, } \\
\%\end{array}$ \\
\hline Never & 1 & 5 & 3.82 \\
\hline Rarely & 2 & 13 & 9.92 \\
\hline Sometimes & 3 & 63 & 48.09 \\
\hline Often & 4 & 30 & 22.90 \\
\hdashline Constantly & 5 & 20 & 15.27 \\
\hline Total & - & 131 & 100 \\
\hline
\end{tabular}

Table 4. The results of the survey "Do you conduct business research using digital tools?"

Source: Calculated by the authors.

\begin{tabular}{c|c|c|c}
\hline $\begin{array}{c}\text { Response } \\
\text { options }\end{array}$ & $\begin{array}{c}\text { Ranking of } \\
\text { response } \\
\text { options }\end{array}$ & $\begin{array}{c}\text { Number of } \\
\text { respondents' } \\
\text { answers }\end{array}$ & $\begin{array}{c}\text { Share of } \\
\text { the total } \\
\text { number of } \\
\text { responses, } \\
\%\end{array}$ \\
\hline Never & 1 & 31 & 23.66 \\
\hline Rarely & 2 & 33 & 25.19 \\
\hline Sometimes & 3 & 24 & 18.32 \\
\hline Often & 4 & 18 & 13.74 \\
\hline Constantly & 5 & 25 & 19.09 \\
\hline Total & - & 131 & 100 \\
\hline
\end{tabular}


An important role in the research is played by the relationship between the dynamics of innovation and the need to implement business research. In this regard, the survey provided a question about the subjective assessment of the dynamics of innovation in the industry (Table 5).

Table 5. Results of the survey "How do you assess the dynamics of innovation growth in your business?"

\begin{tabular}{l|c|c|c} 
& \multicolumn{2}{c}{ Source: Calculated by the authors. } \\
\hline $\begin{array}{c}\text { Response } \\
\text { options }\end{array}$ & $\begin{array}{c}\text { Ranking of } \\
\text { response } \\
\text { options }\end{array}$ & $\begin{array}{c}\text { Number of } \\
\text { respondents' } \\
\text { answers }\end{array}$ & $\begin{array}{c}\text { Share of } \\
\text { the total } \\
\text { number of } \\
\text { responses, } \\
\%\end{array}$ \\
\hline Very low & 1 & 19 & 14.50 \\
\hline Low & 2 & 33 & 25.19 \\
\hline Average & 3 & 43 & 32.83 \\
\hline High & 4 & 20 & 15.27 \\
\hline Very high & 5 & 16 & 12.21 \\
\hline Total & - & 131 & 100 \\
\hline
\end{tabular}

According to the survey results, about $40 \%$ of the respondents rate the innovativeness of their field of activity as "Low" or "Very low".

However, for most SMEs, income has been growing over the past two years (Table 6).

Table 6. The results of the survey "Has your income changed in the last two years?"

\begin{tabular}{|c|c|c|c|}
\hline \multicolumn{4}{|c|}{ Source: Calculated by the authors } \\
\hline Response options & $\begin{array}{l}\text { Ranking } \\
\text { of } \\
\text { response } \\
\text { options }\end{array}$ & $\begin{array}{c}\text { Number of } \\
\text { respondents' } \\
\text { answers }\end{array}$ & $\begin{array}{c}\text { Share of } \\
\text { the total } \\
\text { number of } \\
\text { responses, } \\
\%\end{array}$ \\
\hline $\begin{array}{l}\text { Reduction of more } \\
\text { than } 10 \%\end{array}$ & 1 & 17 & 12.98 \\
\hline Decrease by $5-10 \%$ & 2 & 5 & 3.82 \\
\hline Almost unchanged & 3 & 21 & 16.03 \\
\hline $5-10 \%$ increase & 4 & 25 & 19.08 \\
\hline $\begin{array}{l}\text { Increase by more } \\
\text { than } 10 \%\end{array}$ & 5 & 63 & 48.09 \\
\hline Total & - & 131 & 100 \\
\hline
\end{tabular}

The conflicting results have prompted a deeper study of quantitative relationships. For this purpose, a regression analysis of the obtained data was performed, which gave the following results.

Table 7 systematizes the results of regression analysis for a number of interdependencies. Using re- gression analysis, hypotheses were tested regarding the presence of an "impact-result" relationship (linear dependence) between many studied values. The main parameters of the studied models are:

1) $R$ - the multiple correlation coefficient.

2) $R^{2}$ - the coefficient of determination that characterizes the quality of the model (the higher the value of this parameter, the greater the proportion of values that characterize this model).

3) The coefficients $a$ and $b$, which are the parameters of the linear regression equation $Y=a+$ $b \cdot X$, where: $X$ - variable impact; $Y$ - resulting parameter.

The sign and value of the coefficients $a$ and $b$ help estimate the direction of the connection between $Y$ and $X$, as well as the strength of this connection.

Analysis of the relationship between the dynamics of innovation in the industry and the need for business research (Table 7) showed that the more the economic activity of SMEs requires constant innovation (improvement of products and services, creation of new products, opening of new market niches), the greater the need for enterprises to conduct business research. Parameter $R^{2}=0.862595$. This means that in $86 \%$ of cases, a $1 \%$ increase in industry innovation increases the need for business research by $1.76 \%$ (coefficient $b$ $=1.761364$ ). Thus, if small businesses are looking to scale through innovation, there is inevitably a need for business research.

However, according to Table 7, the dynamics of operational and commercial efficiency does not affect the desire of enterprises to engage in research activities in order to scale and increase competitiveness. Parameter $R^{2}=0.114983$. Consequently, the dynamics of income only in $11 \%$ of cases determines the need for business research. According to the analysis results, the need for business research largely determines the use of digital tools for data analysis (dependence is observed only in $23 \%$ of cases, because $R^{2}=0.234916$ ).

At the same time, the need for business research highly determines the use of Big Data and cloud 
Table 7. Regression analysis results

Source: Calculated by the authors.

\begin{tabular}{|c|c|c|c|c|c|}
\hline$X$ (impact) & $Y$ (result) & $\mathbf{R}$ & $\mathbf{R}^{2}$ & Coefficient $a$ & Coefficient $b$ \\
\hline Innovation dynamics & Need for business research & 0.92876 & 0.862595 & -0.06906 & 1.761364 \\
\hline Business income dynamics & Need for business research & 0.339092 & 0.114983 & 0.089635 & 0.229242 \\
\hline Need for business research & $\begin{array}{l}\text { Use of digital tools for data } \\
\text { analysis }\end{array}$ & 0.484682 & 0.234916 & 0.081865 & 0.224329 \\
\hline Need for business research & $\begin{array}{l}\text { Use of Big Data and cloud } \\
\text { technologies }\end{array}$ & 0.842019 & 0.708997 & 0.107788 & -0.26224 \\
\hline $\begin{array}{l}\text { Conducting business } \\
\text { research }\end{array}$ & Dynamics of business income & 0.890776 & 0.793482 & -0.20776 & 3.230088 \\
\hline
\end{tabular}

technologies. $R^{2}=0.708997$. This means that in $71 \%$ of cases, there is a relationship between the need for business research and the use of Big Data and cloud technologies. However, since coefficient $b=$ -0.26224 , the relationship is reversed, i.e., a $1 \%$ increase in the need for business research leads to a $0.26 \%$ decrease in the use of Big Data and cloud technologies in $71 \%$ of cases. The results show that the need for data analysis and business research encourages SMEs increasingly use highly accessible online tools (targeting, customer search, advertising company, effective promotion). On the other hand, an increase in the level of innovation is likely to increase the need for data analysis. So, to create a new product or a new niche that brings profit, SMEs need to analyze both the external and internal environment. This is highly consistent with the structure of data analysis goals among Ukrainian SMEs.

Regression analysis of the relationship between the intensity of business research and the dynamics of enterprise income showed that there is a strong level of interdependence. $R^{2}=0.793482$, it means that in $79 \%$ of cases there is a relationship between the intensity of business research and the dynamics of the operating income of the enterprise. At the same time, an increase in the intensity of business research by $1 \%$ leads to an increase in operating income by more than $3 \%$ (coefficient $b=3.230088$ ). The effectiveness of business research is not immediately apparent (coefficient $a=-0.20776$ ), i.e., at the initial stages of entrepreneurial research programs, there may be a negative or zero result.

\section{DISCUSSION}

The obtained results allowed identifying patterns that are of great practical importance for small companies that occupy an increasing share in both the national and global economy. However, the significant potential of digital business research for SMEs has created a need for additional research. These can be related to the staffing of business research, as well as the organization of cooperation between SMEs and research agents.

Microenterprises are strongly interested in developing and implementing innovations, since the main source of growth for these companies can be technical developments, knowledge, and commercial data. However, the main obstacle is access to intangible resources. This raises the question of how to build an effective model of the relationship between research agents and SMEs. The main difficulties in building this business model can be:

- mutual misunderstanding of goals and requirements;

- difficulties in articulating the research needs of SMEs;

- limited time for full research and testing;

- lack of interest of researchers in the practical side of business research and its commercialization.

Thus, the study of opportunities and identification of the basic principles of building a model of interaction between research agents and SMEs for the effective implementation of business research is another issue for the development of this research area.

The potential for future developments is created by the presence of issues related to the organization of research activities of small and medium-sized businesses, problems of motivation for the formation and implementation of a knowledge-based business model. 


\section{CONCLUSION}

Small and medium-sized enterprises in Ukraine perform data analysis primarily for the purpose of planning their activities, developing strategies, studying the market, finding customers, recruiting employees, as well as for internal and external analysis. The desire to implement various innovations in professional activities motivates small companies to conduct business research. Thus, the more SMEs seek to scale through innovation, the more they need to conduct business research. Most small business representatives who conduct business research use digital tools, which sharply raises the problems of staff development and building an effective model for outsourcing research agents. Currently, the economic efficiency of business research is not clearly visible. It is due to the influence of strong external factors, as well as a low level of innovation and research activity of economic agents. Nevertheless, the implementation of business research has a significant potential for increasing the income of enterprises.

\section{AUTHOR CONTRIBUTIONS}

Conceptualization: Denys Davydov, Maryna Pasmor.

Formal analysis: Anton Kvitka, Olga Diachek.

Investigation: Anna Kramarenko.

Methodology: Anna Kramarenko, Olga Diachek.

Validation: Denys Davydov, Maryna Pasmor.

Writing - original draft: Anton Kvitka, Anna Kramarenko, Denys Davydov, Maryna Pasmor, Olga

Diachek.

Writing - review \& editing: Anton Kvitka, Maryna Pasmor.

\section{REFERENCES}

1. Alpeza, M., Tall, J., \& Juric, P. M. (2018). The Challenges of SME Business Transfers: The Evidence from Croatia and Finland. Organizacija, 51(2), 135-145. https:// doi.org/10.2478/orga-2018-0012

2. Al-Tal, M. J., \& Emeagwali, O. L. (2019). Knowledge-based HR Practices and Innovation in SMEs. Organizacija, 52(1), 21-26. https:// doi.org/10.2478/orga-2019-0002

3. Anderson, N., Potočnik, K., \& Zhou, J. (2014). Innovation and creativity in organizations: A stateof-the-science review, prospective commentary, and guiding framework. Journal of Management, 40(5), 1297-1333. https://doi. org/10.1177/0149206314527128

4. Andreva, T., \& Kianto, A. (2011). Knowledge processes, knowledgeintensity and innovation: A moderated mediation analysis. Journal of Knowledge Management, 15(6), 1016-1034. https://doi. org/10.1108/13673271111179343

5. Buntak, K., Kovačić, M., \& Martinčević, I. (2020). Impact of digital transformation on knowledge management in organization. Advances in BusinessRelated Scientific Research Journal, 11(1), 37-47. Retrieved from https://www.bib.irb.hr/1072500

6. Černe, M., Kaše, R., \& Škerlavaj, M. (2016). Non-technological innovation research: Evaluating the intellectual structure and prospects of an emerging field. Scandinavian Journal of Management, 32, 69-85. Retrieved from https://daneshyari.com/article/ preview/895756.pdf

7. Chen, Y., \& Fan, B. Q. (2013). Relationship between open innovation capability of SMEs and innovation performance. Research and Development Management, 25, 24-35.

8. Davydov, D. S., Riabovol, D. A., Kramarenko, A. O., \& Kvitka, A. V. (2020). The role of cloud technologies in the digital economy. Biznes Inform, 8, 171-177. https://doi. org/10.32983/2222-4459-2020-8171-177
9. El-Haddadeh, R. (2019). Digital Innovation Dynamics Influence on Organisational Adoption: The Case of Cloud Computing Services. Information Systems Frontiers, 22, 985-999. https://doi. org/10.1007/s10796-019-09912-2

10. Fazal, H., Muhammad, J., \& Zahoor, U. H. (2020). Operational Perspective of SMEs Performance and Competitive Priorities Practices: Path Analytic Approach. Studies in Business and Economics, 15(1), 55-67. https://doi. org/10.2478/sbe-2020-0006

11. Hamburg, I., Vlăduţ, G., \& O'Brien, E. (2017). Fostering eco-innovation in SMEs through bridging research, education and industry for building a business oriented model. Proceedings of the International Conference on Business Excellence, 11(1), 10501057. https://doi.org/10.1515/ picbe-2017-0108

12. Kostrzewska, M., \& Wrukowska, D. (2019). Measuring customer satisfaction in the e-service 
market. Advances in BusinessRelated Scientific Research Journal, 10(2), 58-69. Retrieved from https://www.absrc.org/wpcontent/uploads/2019/12/PAPERKostrzewska.pdf

13. Kramarenko, A., Kvitka, A., Diachek, V., \& Davydov, D. (2019). Cryptocurrencies in the global space: factors and prospects of promotion. SHS Web of Conferences, 67, 06031. https://doi. org/10.1051/shsconf/20196706031

14. Kvitka, A., \& Kramarenko, A. (2018). From big business to small and medium-sized enterprises: factors and prospects. Problems and Perspectives in Management, 16(2), 42-48. http://dx.doi. org/10.21511/ppm.16(2).2018.04

15. Kvitka, A., Kramarenko, A. (2020). Entrepreneurship in the sharing economy: social benefits and digital growth. Investytsii: praktyka ta dosvid - Investment: practice and experience, 1, 64-67. https://doi. org/10.32702/2306-6814.2020.1.64

16. Nemoto, N., \& Koreen, M. (2019). Digital Innovation Can Improve Financial Access for SMEs. Retrieved from https://t20japan.org/wp-content/uploads/2019/03/t20-japantf9-1-digital-innovation-improvefinancial-access-smes.pdf

17. Ogrean, C. (2018). Relevance of Big Data for Business and Management. Exploratory Insights (Part I). Studies in Business and Economics, 13(2), 153-163. https:// doi.org/10.2478/sbe-2018-0027

18. Ogrean, C. (2019). Relevance of Big Data for Business and Management. Exploratory Insights (Part II). Studies in Business and Economics, 14(1), 169-180. https:// doi.org/10.2478/sbe-2019-0013

19. Peček, T. B., \& Ovsenik, M. (2018). Organization, Autopoiesis and Human Potential as Paradigm of the Future Organization. Organizacija, 51(3), 208-218. https:// doi.org/10.2478/orga-2018-0015

20. Perko, I., \& Ototsky, P. (2016). Big Data for Business Ecosystem Players. Naše gospodarstvo/Our Economy, 62(2), 12-24. https://doi. org/10.1515/ngoe-2016-0008
21. Răzvan, Ș. (2019). Several Contemporary Economy Features, Consequences of Internet Expansion and I.C.T. Innovations in the World. Studies in Business and Economics, 14(3), 175-181. https:// doi.org/10.2478/sbe-2019-0052

22. Rissola, G., \& Sorvik, J. (2018). Digital Innovation Hubs in Smart Specializations Strategies. Publications Office of the European Union. http://dx.doi. org/10.2760/475335

23. Rooney, D. (2017). Openness and digital innovation. OECD Observer. https://doi. org/10.1787/7d39e4b1-en

24. Ruggieri, R., Savastano, M., Scalingi, A., Bala, D., \& D’Ascenzo, F. (2018). The impact of Digital Platforms on Business Models: an empirical investigation on innovative start-ups. Management \& Marketing. Challenges for the Knowledge Society, 13(4), 12101225. https://doi.org/10.2478/ mmcks-2018-0032

25. Saunila, M. (2016). Performance measurement approach for innovation capability in SMEs. International Journal of Productivity and Performance Management, 65(2), 162-176. https://doi.org/10.1108/ IJPPM-08-2014-0123

26. Spithoven, A., Vanhaverbeke, W., \& Roijakkers, N. (2013). Open innovation practices in SMEs and large enterprises. Small Business Economics, 41(3), 537-562. https:// doi.org/10.1007/s11187-0129453-9

27. Todericiu, R., \& Boanta, A. (2019). Knowledge Retention within Small and Mediumsized Enterprises. Studies in Business and Economics, 14(3), 231-238. https:// doi.org/10.2478/sbe-2019-0056

28. Vannoni, V. (2019). Financial structure and profitability of innovative SMEs in Italy. Advances in Business-Related Scientific Research Journal, 10(1), 30-41. Retrieved from http://www.absrc. org/wp-content/uploads/2019/06/ PAPER-Vannoni.pdf

29. Vuorio, A., Torkkeli, L., \& Sainio, L. (2020). Service innovation and internationalization in SMEs: antecedents and profitability outcomes. Journal of International Entrepreneurship, 18(1), 92-123. https://doi.org/10.1007/s10843019-00266-Z

30. Wynarczyk, P. (2013). Open innovation in SMEs: A dynamic approach to modern entrepreneurship in the twenty-first century. Journal of Small Business and Enterprise Development, 20(2), 258-278. https://doi. org/10.1108/14626001311326725 